\title{
Lipids profile of bitter melon (Momordica charantia L.) fruit and ebony (Diospyros mespiliformis Hochst ex A. DC.) tree fruit pulp
}

\author{
M. O. Aremu ${ }^{1 *}$, A. A. Waziri $^{1}$, F. J. Faleye ${ }^{2}$, A. M. Magomya ${ }^{1}$ and U. C. Okpaegbe ${ }^{1}$ \\ ${ }^{1}$ Department of Chemical Sciences, Federal University Wukari, PMB 1020, Taraba State, Nigeria \\ ${ }^{2}$ Department of Chemistry, Ekiti State University, PMB 5363, Ado-Ekiti, Nigeria
}

Received:

Revised:

Accepted:

DOI: https://doi.org/10.3329/bjsir.v54i4.44571

\begin{abstract}
There are several underexploited plant seeds or fruits in Nigeria with little information about their chemical composition. To this end a comprehensive study on fatty acid, phospholipids and phytosterols composition of bitter melon (Momordica charaantia) fruit and ebony tree (Diospyros mespiliformis) fruit pulp were determined using standard analytical techniques. The most concentrated fatty acid (\%) was linoleic acid in Momordica charantia fruit (45.47) and 44.82 in Diospyros mespiliformis fruit pulp. The increasing order of the concentrated fatty acids in Momordica charantia fruit were: linolenic acid $(2.38)<$ stearic acid $(7.52)<$ oleic acid $(20.18)<$ palmitic acid $(23.64)<$ linoleic acid (45.47) while that of Diospyros mespiliformis fruit pulp were: linolenic acid $(5.73)<$ stearic acid $(8.62)<$ oleic acid $(18.95)<$ palmitic acid $(20.88)<$ linoleic acid (44.82). Arachidonic, arachidic, palmitoleic, margaric, behenic, erucic, lignoceric, myristic, lauric, capric and caprylic acids were present in small quantities with none of them recording up to $1.0 \%$ in both of the two samples. The results also showed low concentration of monounsaturated fatty acids (MUFA) (20.41\%) in Momordica charantia fruit and $19.13 \%$ in Diospyros mespiliformis fruit pulp, and values of polyunsaturated fatty acid (PUFA) were 2.44 and $5.78 \%$ for the two samples, respectively. The respective phospholipids composition showed a highest concentration of phosphatidylcholine in Momordica charantia and Diospyros mespiliformis (100.31 and $88.12 \mathrm{mg} / 100 \mathrm{~g}$ ) while lysophosphatidylcholine and phosphatidic acid were the least concentrate values of 12.62 and $14.52 \mathrm{mg} / 100 \mathrm{~g}$ in Momordicacharantia and Diospyros mespiliformis, respectively. The concentrations of phytosterols were of low values except in sitosterol with values of 153.28 and $119.46 \mathrm{mg} / 100 \mathrm{~g}$ in Momordica charantia and Diospyros mespiliformis, respectively. This study provides an informative lipid profile that will serve as a basis for further chemical investigations and nutritional evaluation of Momordica charantia fruit and Diospyros mespiliformis fruit pulp.
\end{abstract}

Keywords: Momordica charantia; Diospyros mespiliformis; Fatty acids; Phospholipids; Phytosterols

\section{Introduction}

Plants with their roots, stems, leaves, flowers, fruits and seeds serve as a primary source of foods, fibres, medicines, shelters and other items used in everyday life by humans (Achinewhu, 1998). A large number of plant species are cultivated worldwide as ornamentals, living fences and firebreaks. They are also cultivated as green manures, fodder for livestock, forage for honey bees, food for humans in agro forestry, soil binders and reforestation (for nitrogen fixation), as pulp for paper production, timber, fuel woods and as sources of chemicals and oils (Aremu et al., 2009). They serve as indispensable constituents of human diet supplying the body with mineral salts, vitamins and certain hormone precursors, in addition to protein and energy (Oyenuga, 1968). Nutritive and calorific values of seeds make them necessary in diets (Odoemelam, 2005; Aremu et al., 2010). Plants also represent a major direct source of food for man and livestock, and make a critical contribution to increase food security of subsistence farmers. Apart from inadequate food storage, production, and processing, the demand on food as industrial feed stock by local upcoming industries has

\footnotetext{
*Corresponding author e-mail: lekearemu@gmail.com
} 
also posed serious problem of food insecurity in such regions of the world. Over the years, a number of researchers have investigated the potential suitability of plant seed species in serving as replacement for some of these well-known conventional seed oils. A few of these oil-bearing plant seeds have fruits which have been documented for their nutritional importance (Ihekoronye and Ngoddy, 1985).

Recently, interest has been on the search for lesser known underutilized oil bearing seeds that can serve as source of oil to replace or serve as alternative for the well known conventional seed oils in market which are expensive to afford (NRC, 2008). To address this problem of food insecurity there is need to screen the lesser-known plant seeds for their possible use. In this regard, attention has been focused on underutilized local seeds for possible development and use (Aremu et al., 2017).

Momordica charantia L., known as bitter melon, bitter gourd, bitter squash, or balsam-pear, is fast-growing plant in the wild and abandoned in some villages in Nigeria. Momordica charantia is an herbaceous, tendril-bearing vine grows up to 5 $\mathrm{m}$ in length. It bears simple, alternate leaves 4-12 cm (1.6-4.7 inch) across, with three to seven deeply separated lobes. Each plant bears separate yellow male and female flowers (Ali et al., 2008). The bitter melon fruit has an oblong cucumber-like shape, ranging from 9 to $60 \mathrm{~cm}$ long. But in contrast to cucumbers, it has a very warty-looking exterior. Bitter melon is widely cultivated in tropical and subtropical grown in Asia, Africa and the Caribbean for its edible fruit (Lucas et al., 2010) (Fig 1). Diospyros mespiliformis Hochst ex A. DC. is

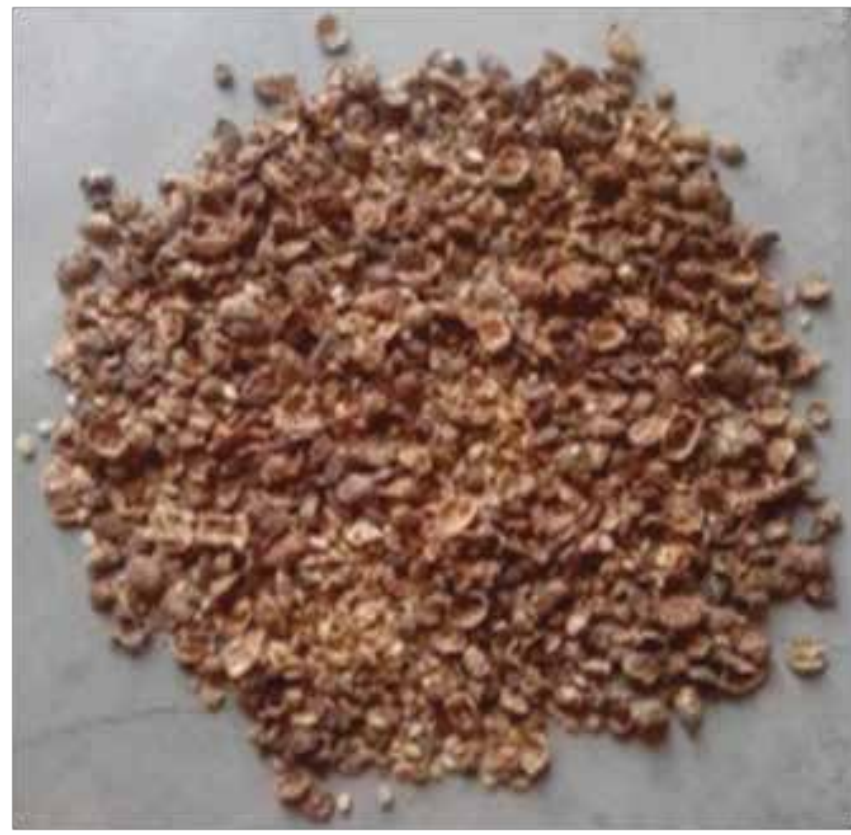

Fig. 1. Dry fruit of bitter melon (Momordica charantia) also known as monkey guava or jackal berry, West Africa ebony. It is an evergreen tree that reaches up to $20 \mathrm{~m}$ in height, or up to $45 \mathrm{~m}$ in forests with a trunk circumference of more than $5 \mathrm{~m}$. It is characterized by a wide spreading and dense canopy and dark grey bark and it is commonly found in tropical Africa, south of the Sahara. It has a dense evergreen canopy. The bark is black to grey, with a rough texture. The fresh inner skin of the bark is reddish. Leaves are simple, alternate, leathery and dark green. The margin is smooth and new leaves in spring are red, especially in young plants. Flowers are cream-coloured and bell-shaped. The fruit is a fleshy berry, with an enlarged calyx, yellow to orange when ripe. Diospyros mespiliformis is dioecious and pollinated by bees. Flowering take place in the rainy season while fruit ripening, which coincides with the dry season takes 6-8 months after flower fertilization. In southern Africa, flowering occurs from October to November and fruiting from April to September (Chivandi et al., 2008) (Fig. 2).

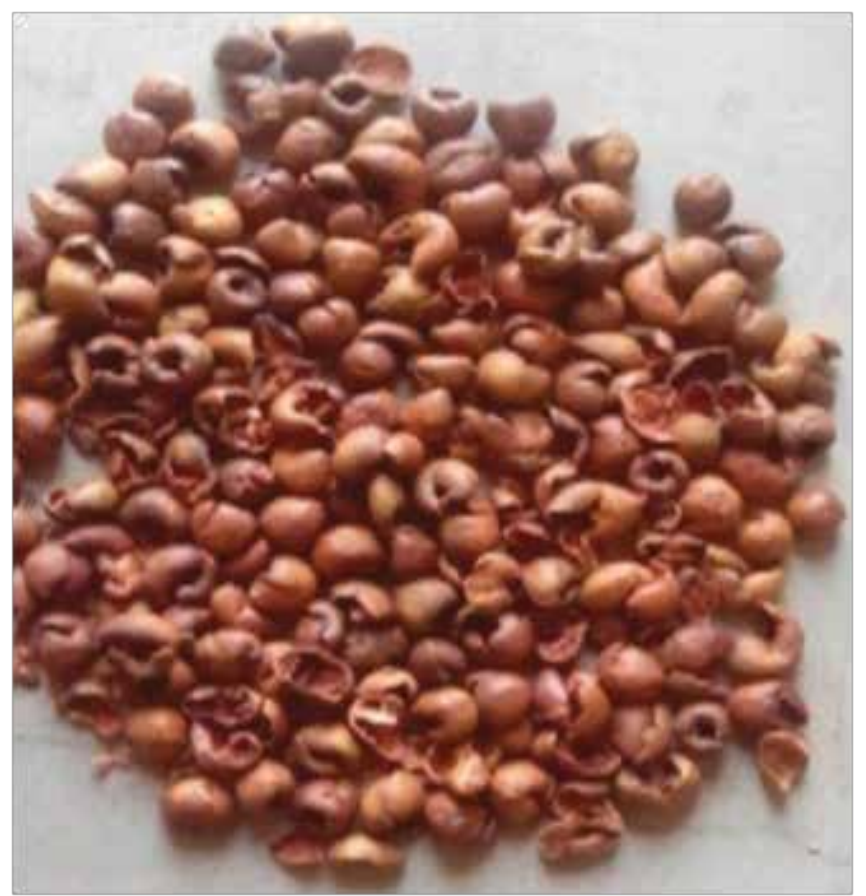

Fig. 2. Dry fruit pulp of ebony tree (Diospyros mespiliformis)

Bitter melon (Momordica charantia) is rich in nutrients like thiamine, beta-carotene, folate, riboflavin and minerals like calcium, iron, phosphorus, manganese, potassium, magnesium, zinc and dietary fiber. Regular use of bitter gourd juice boosts body stamina and prevents chronic fatigue. The beta-carotene content in bitter melon helps in controlling eye disorders and enhances eye light (Leatherdale et al., 1981). Bitter melon stimulates a sluggish digestive system and treats dyspepsia. However, since it promotes secretion of acid, it 
may make an existing ulcerous condition worse. Scientific studies show that fresh juice of bitter melon can lower blood sugar values and keep insulin under check. The hypoglycemic (blood sugar lowering) action is due to the presence of a unique phyto-constituent called charantia, insulin like peptides, and alkaloids, all of which act together to improve glucose tolerance without increasing blood insulin levels (Lucas et al, 2010; Leatherdale et al., 1981).The leaves, bark and roots of ebony tree (Diospyros mespiliformis) contain tannin, which can be used as a styptic to staunch bleeding. The leaves, roots, bark and fruits contain antibiotic qualities and have many medicinal uses in West Africa. Bark and roots are used to treat some infections such as malaria, pneumonia, syphilis, leprosy, dermatomycoses, and to facilitate child birth. Different parts of the plant are used against diarrhea, headache, tooth ache and as a psycho-pharmacological drug (Lucas et al., 2010). The plant is widely used in traditional medicine in parts of Africa, and a number of medically active constituents have been isolated. The principle constituent appears to be plumbagin, which has been shown to have antibiotic, anti-haemorrhagic and fungistatic properties. It is found in the root-bark to a concentration of $0.9 \%$ and but a trace in the leaves (Lajubutu et al., 1995). Tannin, saponin and a substance probably identical to scopolamine are also present. There is a high fluoride content. The leaves are astringent, febrifuge, haemostatic, mildly laxative, stimulant and vermifuge, such reliance is placed on this drug-plant that it is usually prescribed alone (TPD, 2018). The specific objective of this paper is to document the data on fatty acids, phospholipids and phytosterols composition of fruit of bitter melon (Momordica charantia) and ebony tree (Diospyrosmespiliformis) fruit pulp cultivated in north-east Nigeria. This may improve information on food composition table.

\section{Materials and methods}

\section{Sample collection}

Matured fruits of bitter melon (Momordica charantia) and ebony tree (Diospyrosmespiliformis) were collected from a Farmer at Zing local government area of Taraba State, Nigeria.

\section{Sample preparation and treatment}

Bitter melon (Momordica charantia) was prepared by sundried and ground into powder using pestle and mortar, sieved and stored in a well labeled air tight plastic container and taken for analyses. Ebony tree (Diospyros mespiliformis) fruit pulp was prepared by removal of the seeds from the ripe fruit, dried in an air-draught oven at $150^{\circ} \mathrm{C}$ for $6 \mathrm{~h}$. The dried sample of fruit prepared was ground into powder using pestle and mortar, sieved and stored in well labeled air tight plastic container before taken for analyses.

\section{Extraction of oils}

A quantity of $5 \mathrm{~g}$ each of Oven dried sample of bitter melon (Momordica charaantia) fruit and ebony tree (Diospyros mespiliformis) fruit pulp was extracted for $5 \mathrm{~h}$ in Soxhlet apparatus with $250 \mathrm{ml}$ of petroleum ether $\left(40-60^{\circ} \mathrm{C}\right.$ boiling range) of analytical grade (British Drug Houses, London). The extraction flask was removed from the heating mantle when it was almost free of petroleum ether, Oven dried at $105^{\circ} \mathrm{C}$ for $1 \mathrm{~h}$, cooled in a desiccator and used for further analyses (AOAC, 2005).

\section{Fatty acid analysis}

The oil extracted from each sample was converted to the methyl ester using the method described by Adeyeye and Adesina (2015); Aremu et al. (2017). A $50 \mathrm{mg}$ aliquot of the dried oil was saponified for $5 \mathrm{~min}$ at $95^{\circ} \mathrm{C}$ with $3.4 \mathrm{ml}$ of 0.5 $\mathrm{M} \mathrm{KOH}$ in dry methanol. The mixture was neutralized by 0.7 $\mathrm{M} \mathrm{HCl}$ and $3 \mathrm{ml}$ of $14 \%$ boron trifloride in methanol was added. The mixture was heated for $5 \mathrm{~min}$ at $90^{\circ} \mathrm{C}$ to achieve complete methylation. The fatty acid methyl esters were analyzed using a HP gas chromatograph [HP gas chromatograph powered with HP ChemStation rev a09.01 (1206) software (GMI, Inc., Minnesota, USA)] fitted with a flame FID and a computing integrator while nitrogen was used as the carrier gas. The injection port and the detector were maintained at $310^{\circ} \mathrm{C}$ and $350^{\circ} \mathrm{C}$, respectively while the column initial temperature was $250^{\circ} \mathrm{C}$ rising at $5^{\circ} \mathrm{C} / \mathrm{min}$ to a final temperature of $310^{\circ} \mathrm{C}$. A polar (HP INNO Wax) capillary column $(30 \mathrm{~m} \times 0.53 \mathrm{~mm} \times 0.25 \mu \mathrm{m})$ was used to separate the esters. The peaks were identified by comparison with standard fatty acid methyl esters obtained from Sigma Chemical Co. (St. Louis MO, USA) (Aremu et al., 2016). However, the quantitative evaluation was carried out on the base of gas chromatography peak areas of the different methyl esters. The heptadecanoic ester was used to calculate the response factor for fatty acids which was found to be 0.96. Three determinations were made for each sample.

\section{Phospholipid analysis}

The phospholipids content of bitter melon (Momordica charaantia) fruit and ebony tree (Diospyros mespiliformis) fruit pulp oils was determined by gas chromatography (GC) as it was earlier described by Aremu et al. (2017). $0.01 \mathrm{~g}$ of the extracted fats was added to the test tube. To ensure complete dryness of the oil for phospholipids analysis, the solvent was completely removed by passing the stream of the nitrogen gas on the oil. $0.04 \mathrm{~mL}$ of chloroform was added to the 
content of the tube and it was followed by the addition of $0.10 \mathrm{~mL}$ of chromogenic solution. The content of the tube was heated at a temperature of $100^{\circ} \mathrm{C}$ in a water bath for about $1 \mathrm{~min}$. The content was allowed to cool, $5 \mathrm{~mL}$ of the hexane was added and the tube with its content shook gently several times. The solvent and the aqueous layers were recovered and allowed to be separated. The hexane layer was recovered and allowed to be concentrated to $1.0 \mathrm{~mL}$ for gas chromatography using flame photometric detector. The conditions for phospholipid analysis include H.P 5890 powered with HP ChemStation REV. A 09.01 (1206) and split injection ratio of 20:1; nitrogen as carrier gas; inlet temperature, $250^{\circ} \mathrm{C}$; column type, HP5; column dimension: $30 \mathrm{~m} \times 0.25 \mathrm{~mm} \times 0.25 \mu \mathrm{m}$; oven program: Initial temperature at $50^{\circ} \mathrm{C}$; first ramping at $10^{\circ} \mathrm{C} / \mathrm{min}$ for $20 \mathrm{~min}$, maintained for $4 \mathrm{~min}$ while second ramping at $15^{\circ} \mathrm{C} / \mathrm{min}$ for $4 \mathrm{~min}$, maintained for $5 \mathrm{~min}$. Detector: PFPD Detector temperature was $300^{\circ} \mathrm{C}$; hydrogen pressure, $20 \mathrm{psi}$; compressor air: 35 psi (Aremu et al., 2017).

\section{Phytosterol analysis}

The phytosterol analysi was done as described by AOAC (2005) supported by Aremu et al. (2017). The aliquots of the extracted fat were added to the screw - capped test tubes. The samples were saponified at $90^{\circ} \mathrm{C}$ for $30 \mathrm{~min}$, using $3 \mathrm{ml}$ of $10 \% \mathrm{KOH}$ in ethanol, to which $0.20 \mathrm{~mL}$ of benzene had been added to ensure miscibility. Deionized water $(3 \mathrm{~mL})$ was added and $2 \mathrm{~mL}$ of hexane was added in extracting the non saponifiable materials. Three different extractions, each with $2 \mathrm{~mL}$ of hexane were carried out for $1 \mathrm{~h}, 30 \mathrm{~min}$ and $30 \mathrm{~min}$, respectively. The hexane was concentrated to $1 \mathrm{~mL}$ in the vial for gas chromatography analysis and $1 \mu \mathrm{L}$ was injected into the injection pot of GC. The GC conditions of analyses were similar to the GC conditions for methyl esters analyses (Aremu et al., 2016).

\section{Results and discussion}

The fatty acid composition (\%) of bitter melon (Momordica charantia) fruit and ebony tree (Diospyros mespiliformis) fruit pulp are shown in Table I. The results showed that linoleic acid (C18:2) and palmitic acid (C16:0) formed the first and second most abundant fatty acids in Momordica charantia fruit whereas in the case of Diospyros mespiliformis fruit pulp the values are lower. This is in agreement with the report of Grosso et al. (1997) that oleic (C16:0) which is third in concentration in Table I. in both samples are the major fatty acids in many plant seeds such as peanut, soybean and chide pea. Oleic acid has been regarded as monounsaturated fatty acid and has been shown to decrease cholesterol concentrations which affect positively cardiovascular disease risk (Kris-etherton et al., 1999). It is increasingly recognized that an insufficient intake of omega-6 acid such as linoleic causes growth retardation in children, heart attack risk and skin ailments (Baird et al., 2005). It has been reported that many lipids contain substantial amounts of saturated fatty acids especially palmitic acid (Aremu et al., 2007). Stearic acid (C18:0) (7.52 and 8.62\%) takes the fourth position in both samples of Momordica charantia and Diospyros mespiliformis. Lignoceric, behenic, arachidic, arachidonic, margaric, erucic, myristic, lauric, capric, caprylic and butyric acids contained some fatty acids content which is less than $1 \%$.

The fatty acid distribution according to saturation and unsaturation was shown in Table I. The total saturated fatty acids (TSFA) were 31.69 and $30.28 \%$ for Momordica charantia and Diospyrosmespiliformis, these values are greater than TSFA values of 28.15 and $24.05 \%$ reported for Albizia lebbeck and Caesalpinia pulcherrima fruits, respectively (Chivandi et al., 2008). However, the respective values recorded for the total unsaturated fatty acid (TUFA) were 68.31 and $69.72 \%$ for Momordica charantia and Diospyros mespiliformisas shown in Table I. They are higher than that of Albizia lebbeck and Caesalpinia pulcherrima fruits with values of 54.00 and $56.20 \%$, respectively (Chivandi et al., 2008). Total unsaturated fatty acid (TUFA) in this study is of good concern because report has shown that fats and oils with high unsaturation are particularly susceptible to oxidation and intakes of food containing oxidized lipid increase the concentration of secondary proxidation products in liver (Hegested et al., 1993). However, high amount of the total unsaturated fatty acid (TUFA) makes Momordica charantia and Diospyros mespiliformis as a special fruit for nutritional applications. These findings imply that Momordica charantia fruit and Diospyros mespiliformis fruit pulp are good in the supply of essential fatty acids. Linoleic and alpha-linolenic acids called omega-6-and omega-3-fatty acid, respectively are the most important essential fatty acids required for growth, physiological functions and body maintenance (Salunkhe et al., 1985; Aremu et al., 2017). These two fatty acids work together in competitive balance to regulate blood clotting, immune response and inflammatory processes. Deficiency of linoleic acid leads to dry hair or hair loose and poor wound healing (Cunnane and Anderson, 1997). It also leads to poor growth, fatty liver, skin lesion and reproductive failure. It has been reported that linoleic acid plays a role in lowering the risk of cardiovascular disease. It has also been found that the intake of linoleic acid in the diet protects against fatal schemic heart disease (Aremu et al., 2017). Diospyros mespiliformis had the highest TEFA (50.55\%) content. The oleic/linoleic (O/L) level is 0.44 in Momordica charantia fruit and 0.40 in Diospyros mespiliformis fruit pulp. Monounsaturated fatty acid (MUFA) values were 20.41 and $19.13 \%$ in Momordica charantia fruit and Diospyros 
Table I. Fatty acids composition of Momordica charantia fruit and Diospyros mespiliformis fruit pulp and distribution into the degree of saturation and unsaturation of the component

\begin{tabular}{lcc}
\hline Fatty acid & Momordica charantia & Diospyros mespiliformis \\
\hline Caprylic acid (C8:0) & 0.000 & 0.000 \\
Capric acid (C4:0) & 0.000 & 0.000 \\
Lauric acid (C12:0) & 0.000 & 0.000 \\
Myristic acid (C14:0) & 0.000 & 0.000 \\
Palmitic acid (C16:0) & 23.64 & 20.88 \\
Palmitoleic acid (C16:1) & 0.11 & 0.09 \\
Margaric acid (C17:0) & 0.01 & 0.01 \\
Stearic acid (C18:0) & 7.52 & 8.62 \\
Oleic acid (C18:1) & 20.18 & 18.95 \\
Linoleic acid (C18:2) & 45.47 & 44.82 \\
Linolenic acid (C18:3) & 2.38 & 5.73 \\
Arachidic acid (C20:0) & 0.22 & 0.53 \\
Arachidonic acid (20:4) & 0.06 & 0.04 \\
Behenic acid (22:0) & 0.09 & 0.07 \\
Erucic acid (C22:1) & 0.12 & 0.09 \\
Lignoceric acid (C24:0) & 0.22 & 0.17 \\
TSFA & 31.69 & 30.28 \\
TSFA (\%) & 31.69 & 30.28 \\
MUFA & 20.41 & 19.13 \\
DUFA & 45.47 & 44.82 \\
PUFA & 2.44 & 5.78 \\
TUFA & 68.31 & 69.72 \\
TUFA (\%) & 68.31 & 68.31 \\
TEFA & 47.85 & 50.55 \\
TNEFA & 52.15 & 49.45 \\
O/L & 0.44 & 0.44 \\
\hline & -50 \\
\hline
\end{tabular}

TSFA = Total saturated fatty acid, MUFA = Monounsaturated fatty acid, DUFA= Diunsaturated fatty acid, PUFA = Polyunsaturated fatty acid, TUFA = Total unsaturated fatty acid, TEFA $=$ Total essential fatty acid, TNEFA $=$ Total nonessential fatty acid, $\mathrm{O} / \mathrm{L}=\mathrm{Oleic} /$ Linoleic ratio

mespiliformis fruit pulp, respectively while polyunsaturated fatty acid (PUFA) values were 2.44 and $5.78 \%$. Diunsaturated fatty acid (DUFA) values for both the samples were 45.47 and $44.81 \%$. Linoleic acid constituted the DUFA while total nonessential fatty acid (TNEFA) gave 52.15 and $49.51 \%$ for Momordica charantia fruit and Diospyros mespiliformis fruit pulp, respectively.
The phospholipids content of Momordica charantia fruit and Diospyros mespiliformis fruit pulp is presented in Table II. From the result phosphatidylcholine showed greater concentrations in Momordica charantia fruit $(100.31 \mathrm{mg} / 100 \mathrm{~g})$ and Diospyros mespiliformis fruit pulp (88.12 mg/100 g). Phosphatidylserine came second with values of 69.37 and $50.14 \mathrm{mg} / 100 \mathrm{~g}$ for both Momordica charantia and Diospyros mespiliformis. Phosphatidylinsitol in the case of 
Table II. Phospholipids composition (mg/100 g) of Momordica charantia fruit and Diospyros mespiliformis fruit pulp

\begin{tabular}{lcc}
\hline Phospholipids & $\begin{array}{c}\text { Momordica } \\
\text { charantia }\end{array}$ & $\begin{array}{c}\text { Diospyros } \\
\text { mespiliformis }\end{array}$ \\
\hline Phosphatidylethanolamine & 22.57 & 16.02 \\
Phosphatidylcholine & 100.31 & 88.12 \\
Phosphatidylserine & 69.37 & 50.14 \\
Lysophoshatidylcholine & 12.62 & 20.54 \\
Phosphatidylinsitol & 40.77 & 17.10 \\
Phosphatidic acid & 20.68 & 14.52 \\
\hline
\end{tabular}

Momordica charantia followed phosphatidylserine with the value $(40.77 \mathrm{mg} / 100 \mathrm{~g})$ but it was lysophosphatidylcholine (20.54 mg/100 g)in Diospyros mespiliformis (Table II). The fourth and fifth most concentrated phospholipids in Momordica charantia were phosphatidylethanolamine and phosphatidic acid with concentrations of 22.57 and 20.68 $\mathrm{mg} / 100 \mathrm{~g}$ while fourth and fifth most concentrated phospholipids in Diospyros mespiliformis were phosphatidylinsitol and phosphatidylethanolamine whoseconcentrated values were 18.00 and $16.02 \mathrm{mg} / 100 \mathrm{~g}$. Lysophosphatidylcholine and phosphatidic acid were the least concentrated values of 12.62 and $14.52 \mathrm{mg} / 100 \mathrm{~g}$ in Momordica charantia fruit and Diospyros mespiliformis fruit pulp, respectively. Contrary to report of Wirtz (1991) that phosphatidylethanolamine is usually the most abundant phospholipids in animals and plants, often amounting to almost $50 \%$ of the total phospholipids, and as such they are building block of membrane bilayer and being the reason researchers have recommended daily supplementation of phosphatidylcholine as a way of improving brain functioning memory capacity (Chung et al., 1995). Therefore, consumption of any of these samples in the present study may not require supplementation of phosphatidylcholine because of sufficient concentration of this phospholipid. The US Food and Drug Administration (USFDA) has reported that consumption of phosphatidylserine may reduce the rate of dementia and cognitive dysfunction in the elderly people and in young people it reduces mental stress and increases mental accuracy and stress resistance (Wang and Jones, 2004). Phosphatidylserine supplementation promotes a desirable hormonal balance for athletes and might reduce the physiological deterioration that accompanies over training and /or overstretching (Starks et al., 2008). Phosphatidic acid mediates cellular functions through different modes of action, such as membrane tethering, modulation of enzymatic activities and structural effects on cell membranes. The regulatory processes in which phosphatidic acid plays a role include; signaling pathways in cell growth, proliferation, reproduction and responses to hormones in biotic and abiotic stress (Wang and Jones, 2004). Therefore, consumption of these plant fruits particularly Momordica charantia may participate well in these functions. From the result Momordica charantia fruit has more total concentrated value of phospholipids than Diospyros mespiliformis fruit pulp, consequently Momordica charantia fruit can be regarded as a better source of phospholipids as compared to Diospyros mespiliformis fruit pulp.

The compositions of phytosterols in Momordica charantia fruit and Diospyros mespiliformis fruit pulp are displayed in Table III. in which sitosterol in both samples carried the highest concentrations (153.28 and $119.46 \mathrm{mg} / 100 \mathrm{~g}$ ) followed by campesterol $(17.80$ and $9.62 \mathrm{mg} / 100 \mathrm{~g})$ in

Table III. Phytosterols composition (mg/100 g) of Momordica charantia fruit and Diospyros mespiliformis fruit pulp

\begin{tabular}{lcc}
\hline Sterols & $\begin{array}{c}\text { Momordica } \\
\text { charantia }\end{array}$ & $\begin{array}{c}\text { Diospyros } \\
\text { mespiliformis }\end{array}$ \\
\hline Cholesterol & 0.79 & 0.74 \\
Cholestanol & $1.75 \times 10^{-6}$ & $2.92 \times 10^{-6}$ \\
Ergosterol & $1.71 \times 10^{-6}$ & $1.78 \times 10^{-6}$ \\
Campesterol & 17.80 & 9.62 \\
Stigmasterol & 4.13 & 6.00 \\
Savenasterol & 0.83 & 1.15 \\
Sitosterol & 153.28 & 119.46 \\
\hline
\end{tabular}

Momordica charanta fruit and Diospyros mespiliformis fruit pulp. The third and fourth most concentrated phytosterols in Momordica charantia were 5-avenasterol and cholesterol with values of 0.83 and $0.79 \mathrm{mg} / 100 \mathrm{~g}$ while that of Diospyros mespiliformis were cholesterol and stig-masterol $(0.73$ and $6.000 \mathrm{mg} / 100 \mathrm{~g}$ ). The values for stig-masterol, cholestanol and ergosterol in Momordica charantia were 4.133, $1.75 \mathrm{x}$ $10^{-6}$ and $1.71 \times 10^{-6} \mathrm{mg} / 100 \mathrm{~g}$ while cholestanol, ergosterol and 5avenasterol in Diospyros mespiliformis were $2.92 \mathrm{x}$ $10^{-6}, 1.78 \times 10^{-6}$ and $1.15 \mathrm{mg} / 100 \mathrm{~g}$. The result showed that Momordica charantia fruit can be regarded as a better source of phytosterols when compared with Diospyros mespiliformis fruit pulp. Phytosterols are natural components of plant origin forming cell membrane and occur in small quantities in many fruits, cereals, legumes and other plants. Plant phytosterols have also been described as anti-inflammatory and anti-cancer compound (Rao and Koratkar, 1997) while daily intake of phytosterols helps to prevent heart disease by lowering high density lipoprotein cholesterol levels by as 
much as 14\% (Normen et al., 2005). Systematic reviews studying the efficacy of phytosterols have shown that phytosterols enriched foods can significantly lower low density lipoprotein cholesterol (Law, 2000). Phytosterols have been found useful in treating other conditions, including rheumatoid arthritis, but their widest application is in protecting the heart. However, reports also suggest that excessive intake of dietary phytosterols and stanols in plasma and tissues may contribute to an increase in blood pressure (Chen et al., 2010). Through competition of phytosterols with cholesterol absorption and uptake in the small intestine, the supply of cholesterol reduction as a result of uptake of phytosterols in turn reduces the risk of heart disease (coronary heart disease) since high blood total cholesterol and low-density lipoprotein (LDL) cholesterol levels are the main risk factors for coronary heart disease (Aremu et al., 2016)

\section{Conclusion}

The present work has focused on the lipid composition of Momordica charantia fruit and Diospyros mespiliformis fruit pulp. The work revealed that the fruit and fruit pulp contained high proportion of unsaturated fatty acids and significant contents of phospholipids and phytosterols. This study further reveals that Momordica charantia fruit has high lipid content compared to Diospyros mespiliformis fruit pulp and therefore could be exploited as a natural source of relevant lipid content. Momordica charantia fruit was rich in unsaturated fatty acids with potential beneficial therapeutic activities. This study provides an informative lipid profile that will serve as a basis for further chemical investigations and nutritional evaluation of the Momordica charantia fruit and Diospyros mespiliformis fruit pulp.

\section{Conflict of Interest}

Authors have declared that there are no conflicts of interest in the study.

\section{References}

Achinewhu SC (1998), Nuts and seeds. In: Nutritional Qualities of Plants Foods, Eds. Osagie AU and Offiong UE, pp 154-159.

Adeyeye EI and Adesina AJ (2015), Lipid composition of the brains of she-goat and castrated goat consumed in Ekiti State, Nigeria. Bangladesh Journal of Science and Industrial Research 50(2): 153 - 162. DOI: https://doi.org/10.3329/bjsir.v50i2.24357

Ali MA, Sayeed MA, Reza MS, Yeasmin MS and Khan AM (2008), Characteristics of seed oils and nutritional compositions of seeds from different varieties of
Momordicacharantia Linn, cultivated in Bangladesh.Czechoslovakia Journal of Food Science 26(4): 275-83.

AOAC 2005, Official Methods of Analysis. $18^{\text {th }}$ Ed., Association of Official Analytical Chemists, Washington DC,USA.

Aremu MO, Ibrahim H and Aremu SO (2016), Lipid composition of black variety of raw and boiled tiger nut (Cyperus esculentus L.) grown in north - east Nigeria. Pakistan Journal of Nutrition 15(5): 427-438.

Aremu MO, Ibrahim H and Andrew C (2017), Comparative studies on the lipid composition of blood plum (Haematostanze barteri) pulp and seed oils, The Open Biochemistry Journal 11: 94-104.

Aremu MO, Ogunlade I and Olonisakin A (2007), Fatty acid and amino acid composition of cashew nut (Anarcadium occidentale) protein concentrate, Pak. J. Nutrition 6(5): 419 - 423.

Aremu MO, Olaofe O, Basu SK, Abdulazeez G and Acharya SN (2010), Processed cranberry bean (Phaseolus coccineus) seed flours for African diet, Canadian Journal of Plant Science 90: 719 - 728. DOI: org/10.4141/CJPS09149

Aremu MO, Olayioye YE and Ikokoh PP (2009), Effect of processing on the nutritional quality of Kerstingella geocarpa seed flour, Journal of Chemical Society of Nigeria 34(2): 140-149.

Baird J, Fisher D, Lucas P, Kleijnen J, Roberts H and Law C (2005), Beingbig or growing fast: systematic review of size and growth in infancy and later obesity, B.M.J 331: 929-934. DOI: org/10.1136/ bmj.38586. 411273.E0

Chen Q, Gruber H, Swist E, Coville K, Pakenham C, Ratnayake WMN and Scoggern K (2010), Dietary phytosterols and phytostanols decrease cholesterol levels but increase blood pressured and WKY in bred rats in the absence of salt load loading, Nutrition and Metabolism 7(1): $11-20$.

Chivandi A, Erlwanger KH and Davidson BC (2008), Lipid content and fatty acid profileof the fruit seeds of Diospyrosmespiliformis, International Journal of IntegrativeBiology 5(2): 121-124. 
Chung HM, Sun JM, Morell MJ and Houpian DS (1995), Intracerebral involvement in selerodema en coup de sarbre, report of a case with neuropathogenic finding, Annalof Neurology 37: 679-681.

Cunnane S and Anderson M (1997), Pure linoleate deficiency in the rat: influence on growth, accumulation of $n-6$ polyunsaturates and (1-14C) linoleate oxidation, Journal of Lipid Research 38: 805-812.

Fulman J and Oz MC (2003), Eat to live: The Revolutionary Plan for Fast and Sustained Weight Loss. $1^{\text {st }}$ Ed., Little, Brown and Co., USA., ISBN-13:978-0316829458, pp 224.

Grosso NR, Zygadlo JA, Lamarque AL, Maestri DM and Guzman CA (1997), Proximate, fatty acid and sterol compositions of aboriginal peanut (Arachis hypogaea L.) seeds from Bolivia, Journal of Science, Food and Agriculture 73: $249 \quad-\quad 356 . \quad$ DOI:org/10. 1002/(SICI)1097-0010

Hegested DM, Dusman LM, Johnson JA and Dallal DE (1993), Dietary fat and serum lipids; an evaluation of the experimental data, American Journal of Clinical Nutrition 57: 875-883.

Ihekoronye AI and Ngoddy PO (1985), Integrated Food Science and Technology ISBN 97894007-17640.

Kris-Etherton PM, Pearson TA, Wan Y, Hargrove RL, MoriartyK, Fishell V and Etherton TD (1999), High-monounsaturated fatty acid diets lower both plasmacholesterol and triacylglycerol concentrations, American Journal Clinical Nutrition 70: 1009-1015. DOI: org/10.1093/ajen/70.6.1009

Lajubutu AA, Pinney RJ, Roberts MF, Odelola HA and Oso BA (1995), Antibacterialactivity of diosquinone and plumbagin from the root of Diospyros mespiliformis (Hostch) (Ebenaceae), Phytother. Res. 9: 346-350. DOI: org/10.1093/ajcn/70.6.1009

Law M (2000), Plant sterol and stanol margarines and health. British Medical Journal 320: 861 - 864.

Leatherdale BA, Panesar RK and Singh G (1981), Improvement in glucose tolerance due toMomordica charantia (Karela). British Medical Journal (Clin. Res. Ed) 282:1823-1824.

Lucas AA, Dumancas GG, Smith BJ, Clarke SL and Arjmandi BF (2010), Health Benefits of Bitter Melon (Momordica charantia) In: Bioactive Foods in Promoting Health, Eds. Ronald RW and Victor RP,
Academic Press, San Diego, pp 525-549.

NRC (National Research Council) (2008), Ebony Lost Crops of Africa: Volume III: Fruits: LostCrops of Africa. 3. National Academics Press, ISBN 978-0-309-10596-5. Retrieved

Normen F, Holmes LD and Frohlich J (2005), Plant sterols and their role in combined use with statins for lipid lowering, Current Opin. Invest. Drugs 2: 307 - 316.

Odoemelam SA (2005), Proximate composition and selected physicohemical properties of the seeds of African oil bean (Pentaclethra marcrophylla), Pakistan Journal Nutrition 4: 382 - 383 .

Oyenuga VA (1968), Nigerian Foods and Feeding Stuff, $3^{\text {rd }}$ Ed., Nigerian University Press, Ibadan, Nigeria.

Rao Y and Koratkar R (1997), Anti-carcinogenic effects of saponins and phytosterols. Amerian Chemical Society 18: $313-324$.

Salunkhe DK, Kadam SS and Chavan JK (1985), Postharvest Biotechnology of Food Legumes, CRC Press, Boca Raton, FL.

Starks MA, Starks SL, Kingsley M, Purpura M and Jager R (2008), The effects of phosphatidylserine endocrine response to moderate intensity exercise, International Society of Sports \& Nutrition 5: 11-16.

Tropical Plants Database (TPD) (2018), Ken Fern Tropical. The ferns information.Tropics, Macmillan, New York, USA.

Wang YM and Jones PJH (2004), Conjugated linoleic acid and obesity control, efficacy and mechanism, International Journal of Obes. 941-955. DOI: 10:1038/sj.ijo.0802641.

Wirtz KW (1991), Phospholipid transfer proteins: From lipid monolayers to cells, Klin Wochenschr 69(3): 105-11. 